\title{
Bicarbonate Modulates Oxidative and Functional Damage in Ischemia-Reperfusion
}

\author{
Bruno B. Queliconi ${ }^{1}$, Thire B. M. Marazzi ${ }^{1}$, Sandra M. Vaz ${ }^{1}$, Paul S. Brookes ${ }^{2}$, Keith \\ Nehrke $^{2}$, Ohara Augusto ${ }^{1}$, and Alicia J. Kowaltowski ${ }^{1, \#}$ \\ ${ }^{1}$ Departamento de Bioquímica, Instituto de Química, Universidade de São Paulo, São Paulo, SP, \\ Brazil \\ 2University of Rochester Medical Center, Rochester, NY, USA
}

\begin{abstract}
The carbon dioxide/bicarbonate $\left(\mathrm{CO}_{2} / \mathrm{HCO}_{3}{ }^{-}\right)$pair is the main biological $\mathrm{pH}$ buffer. However, its influence on biological processes, and in particular redox processes, is still poorly explored. Here we study the effect of $\mathrm{CO}_{2} / \mathrm{HCO}_{3}{ }^{-}$on ischemic injury in three distinct models (cardiac $\mathrm{HL}-1$ cells, perfused rat heart and C. elegans). We found that, while different concentrations of $\mathrm{CO}_{2} / \mathrm{HCO}_{3}{ }^{-}$ do not affect function under basal conditions, ischemia-reperfusion or similar insults in the presence of higher $\mathrm{CO}_{2} / \mathrm{HCO}_{3}{ }^{-}$resulted in greater functional loss associated with higher oxidative damage in all models. Since the effect of $\mathrm{CO}_{2} / \mathrm{HCO}_{3}{ }^{-}$was observed in all models tested, we believe this buffer is an important determinant of oxidative damage following ischemiareperfusion.
\end{abstract}

\section{Introduction}

$\mathrm{CO}_{2}$, formed in a multitude of intracellular reactions, is hydrated in a reaction catalyzed by carbonic anhydrase to carbonic acid $\left(\mathrm{H}_{2} \mathrm{CO}_{3}\right)$, which de-protonates generating bicarbonate $\left(\mathrm{HCO}_{3}{ }^{-}\right)$. The $\mathrm{CO}_{2} / \mathrm{HCO}_{3}{ }^{-}$pair, with a pKa of 6.4 , is the main physiological buffer, due mostly to the high concentration in biological compartments (extracellular fluid $\mathrm{pH}$ ranges are 7.2; Ezraty et al., 2011; Guais et al., 2011).

Interestingly, despite its ubiquity and abundance, biological activities of the $\mathrm{CO}_{2} / \mathrm{HCO}_{3}{ }^{-}$ pair have received very little attention, probably because there is little ability to control concentrations in vivo. Bicarbonate buffer, which is composed of $\sim 1.3 \mathrm{mM} \mathrm{CO}_{2}$ in equilibrium with $25 \mathrm{mM} \mathrm{HCO}_{3}{ }^{-}$in serum and $14 \mathrm{mM} \mathrm{HCO}_{3}{ }^{-}$intracellularly, has welldemonstrated redox effects (see Medinas et al., 2007 for a review). The first suggestion in this sense came from Hodgson and Fridovich in 1976, who reported that xanthine oxidasecatalyzed luminescence was dependent on the presence of carbonate. After that, a series of studies demonstrated that the presence of $\mathrm{CO}_{2} / \mathrm{HCO}_{3}{ }^{-}$stimulates the oxidation, peroxidation and nitration of different biomolecules (Bonini et al. 2004; Zhang et al. 2003; Liochev and Fridovich, 2004; Radi, 2004; Arai et al. 2005; Medinas et al. 2009; Surmeli et al. 2010;

\footnotetext{
\#To whom correspondence should be addressed: Av. Prof. Lineu Prestes, 748, Cidade Universitária, São Paulo, SP, Brazil, 05508-900, Fax: +55 1138155579 , alicia@iq.usp.br.
} 
Zhou et al. 2011). The mechanism through which $\mathrm{CO}_{2} / \mathrm{HCO}_{3}{ }^{-}$stimulates these oxidations has been elucidated for peroxynitrite-mediated processes but remains uncovered in most cases due to methodological difficulties involving the detection of highly reactive intermediates, such as the carbonate radical (see Medinas et al., 2007 for a review).

Most studies addressing the role of $\mathrm{CO}_{2} / \mathrm{HCO}_{3}{ }^{-}$in biological oxidations have been exclusively conducted in in vitro or, less commonly, in vivo systems to which oxidants were added exogenously promoting overt oxidative stress followed by an evaluation of the effects of $\mathrm{HCO}_{3}{ }^{-}$(Ezraty et al., 2011). This still leaves open the question if $\mathrm{CO}_{2} / \mathrm{HCO}_{3}{ }^{-}$levels are relevant for oxidative injury resulting from reactive oxygen species (ROS) generated endogenously in vivo under physiological or pathological conditions. The question is highly relevant since, due to their reactive and diverse nature, ROS effects are mostly resultant from localized intracellular reactions (Winterbourn, 2008, Cardoso et al., 2012). In addition, quantities of added oxidants may differ very significantly from those produced intracellularly, even under pathological conditions. The demonstration that $\mathrm{CO}_{2} / \mathrm{HCO}_{3}{ }^{-}$ levels affect tissues under physiologically relevant conditions would provide evidence, albeit indirect, of the participation of carbonate radicals in biologically relevant processes (Medinas et al., 2007).

In order to address this point, we chose to study the effects of $\mathrm{CO}_{2} / \mathrm{HCO}_{3}{ }^{-}$in ischemiareperfusion (IR). IR occurs in important pathological conditions such as heart attack and stroke and involves a burst in ROS production and oxidative damage, mainly during reperfusion, that are determinant toward the final outcome of tissue damage (Martin et al., 1996; Vanden Hoek et al., 1996; Facundo et al., 2006). Furthermore, because of the nature of these pathologies, which involve changes in local tensions of diluted gasses and modifications from oxidative to fermentative metabolism, $\mathrm{CO}_{2} / \mathrm{HCO}_{3}{ }^{-}$levels are expected to change during IR, and may, thus, have an important role in determining the extent of postischemic lesions.

The effects of $\mathrm{CO}_{2} / \mathrm{HCO}_{3}{ }^{-}$levels on functional and oxidative damage following IR were tested in three distinct models, under conditions in which external $\mathrm{pH}$ was clamped despite the changes in $\mathrm{CO}_{2} / \mathrm{HCO}_{3}{ }^{-}$concentrations. Our results show that $\mathrm{CO}_{2} / \mathrm{HCO}_{3}{ }^{-}$levels contribute strongly toward post-ischemic functional loss and oxidative damage.

\section{Materials and Methods}

\section{Materials}

All chemicals were of the highest purity available from Sigma (St. Louis, MO), unless otherwise specified. BCECF was purchased from Molecular Probes (Eugene, OR). Antibody sources are described in Western blot section.

\section{Isolated Heart Perfusion}

Heart perfusion was conducted as described previously (Facundo et al., 2006). Briefly, hearts were rapidly removed from male Sprague-Dawley rats ( $\sim 300 \mathrm{~g}, 2-3$ months), and Langendorff-perfused with oxygenated Krebs-Henseleit buffer (described below). Hearts were eliminated from the study if the time between rat death and the beginning of perfusion 
was longer than $3 \mathrm{~min}$. All studies were conducted in accordance with guidelines for animal care and use established by the Colégio Brasileiro de Experimentação Animal and approved by the local animal ethics committee.

After isolation, the hearts were stabilized for $50 \mathrm{~min}$ then submitted to a $30 \mathrm{~min}$ ischemia and $60 \mathrm{~min}$ reperfusion. The reperfusion was conducted with buffers containing 0,5 and $10 \% \mathrm{CO}_{2}$. The buffer for $0 \% \mathrm{CO}_{2}$ contained (in mmol/L) $118 \mathrm{NaCl}, 1.2 \mathrm{KH}_{2} \mathrm{PO}_{4}, 4.7 \mathrm{KCl}$, $1.2 \mathrm{MgSO}_{4}, 1.25 \mathrm{CaCl}_{2}, 10$ glucose, and $20 \mathrm{Na}^{+}$-HEPES, pH 7.4 gassed with pure $\mathrm{O}_{2}$, at $37^{\circ} \mathrm{C}$, for $5 \%$ (in mmol/L) $118 \mathrm{NaCl}, 17 \mathrm{NaHCO}_{3}, 1.2 \mathrm{KH}_{2} \mathrm{PO}_{4}, 4.7 \mathrm{KCl}, 1.2 \mathrm{MgSO}_{4}, 1.25$ $\mathrm{CaCl}_{2}, 10$ glucose, and $20 \mathrm{Na}^{+}$-HEPES, $\mathrm{pH} 7.4$, at $37^{\circ} \mathrm{C}$ gassed with $95 \% \mathrm{O}_{2}+5 \% \mathrm{CO}_{2}$, and for $10 \%$ (in mmol/L) $118 \mathrm{NaCl}, 25 \mathrm{NaHCO}_{3}, 1.2 \mathrm{KH}_{2} \mathrm{PO}_{4}, 4.7 \mathrm{KCl}, 1.2 \mathrm{MgSO}_{4}, 1.25$ $\mathrm{CaCl}_{2}, 10$ glucose, and $20 \mathrm{Na}^{+}$-HEPES, pH 7.4, at $37^{\circ} \mathrm{C}$ gassed with $90 \% \mathrm{O}_{2}+10 \% \mathrm{CO}_{2}$. L-NAME $(200 \mu \mathrm{M})$, when present, was added $10 \mathrm{~min}$ before ischemia and remained in the perfusate until the end of the reperfusion time.

Hemodynamic data were obtained using an electrode connected to a Powerlab Langendorff apparatus from ADInstruments. The pressure transducer was connected to a latex balloon and placed inside the left ventricle, as described previously (Facundo et al., 2006).

\section{Infarcted Area}

Quantification of the infarcted area was conducted as previously described (Fishbein et al., 1981; Budas et al., 2010). Briefly, after reperfusion the heart was sliced and incubated in 1\% triphenyltetrazolium chloride for $15 \mathrm{~min}$. The infarcted area was quantified using Image $\mathbf{J}$ and is presented as a percentage of the total area of the slice. Each heart was sliced in 3 places and the areas from both sides were quantified by an unblinded scorer and averaged.

\section{Cardiac HL-1 cell cultures and simulated cellular IR}

Cardiac HL-1 cells were kindly donated by Professor William C. Claycomb. These cells maintain their cardiac phenotype during extended passages and present ordered myofibrils, cardiac-specific junctions and voltage-dependent currents that are characteristic of a cardiac myocyte phenotype (Claycomb et al., 1998). For routine growth, HL-1 cells were maintained in T-75 flasks at $37^{\circ} \mathrm{C}$ in an atmosphere of $5 \% \mathrm{CO}_{2}$ in Claycomb medium (Sigma) supplemented with $0.1 \mathrm{mM}$ norepinephrine, $100 \mathrm{U} / \mathrm{mL}$ and $100 \mathrm{U} / \mathrm{mL}$ penicillin/ streptomycin, $2 \mathrm{mM}$ glutamine, and 10\% fetal bovine serum. Experiments were conducted at $100 \%$ confluence, after trypsinization and resuspension in a standard buffer $(\mathrm{pH} 7.4)$ containing (in mmol/L): $137 \mathrm{NaCl}, 20 \mathrm{Na}$-Hepes, 22 glucose, 5 Na-pyruvate, 20 taurine, 5 creatine, $5.4 \mathrm{KCl}, 1 \mathrm{MgCl}_{2}$, and $1 \mathrm{CaCl}_{2}$.

Cell IR was simulated as previously described (Facundo et al., 2005; Facundo et al., 2006). Briefly, $10^{6}$ cells $/ \mathrm{mL}$ were submitted to simulated ischemia by metabolic inhibition using 50 $\mathrm{mM}$ KCN and $2 \mathrm{mM}$ 2-deoxyglucose added to standard cell buffer devoid of glucose and pyruvate for $90 \mathrm{~min}$, followed by $5 \mathrm{~min}$ centrifugation and resuspension of the cell pellet in experiment buffer for simulated reperfusion. Control HL-1 cardiomyocytes were incubated with standard buffer solution during the entire experimental period, and submitted only to centrifugations and washes. The standard buffer was gassed with $100 \% \mathrm{O}_{2}$ for the $0 \% \mathrm{CO}_{2}$ 
condition, and $25 \mathrm{mM} \mathrm{NaHCO}_{3}$ was added to a buffer gassed with a mixture of $90 \% \mathrm{O}_{2}+$ $10 \% \mathrm{CO}_{2}$ for $10 \% \mathrm{CO}_{2}$ conditions.

\section{Cell viability}

Cell viability was assessed by relative fluorescence of $50 \mu \mathrm{M}$ ethidium bromide (SigmaAldrich) using a Hitachi F4500 spectrofluorometer at excitation and emission wavelengths of 365 and 580 nm, respectively (Karsten, 1980; Facundo et al., 2005; Facundo et al., 2006). Cells were permeabilized with $0.1 \%$ Triton at the end of the each experiment to promote $100 \%$ cell death. The autofluorescence of ethidium bromide was subtracted from total fluorescence in the presence of cells, ethidium bromide and Triton. Data are expressed as the percentage of total cells.

\section{Intracellular pH measurements}

$\mathrm{pH}$ measurements were conducted using the highly sensitive intracellular probe BCECF, with modifications of a described method (Rink et al., 1982; Johnson and Nehrke, 2010). Cells were trypsinized, washed and resuspended in experimental buffer (described in the cell IR protocol) twice. Cells $\left(10^{6} / \mathrm{mL}\right)$ were incubated with $5 \mu \mathrm{M}$ of BCECF for $90 \mathrm{~min}$, pelleted and resuspend in experimental buffer. The readings were conducted using a Hitachi F4500 spectrofluorometer with fixed emission at $535 \mathrm{~nm}$. The excitation was scanned from 400 to $550 \mathrm{~nm}$. After the measurement of the baseline fluorescence, calibration was conducted adding $10 \mathrm{mg} / \mathrm{mL}$ nigericin to allow from proton exchange across the plasma membrane and adding $\mathrm{NaOH}$ and $\mathrm{HCl}$ to promote maximal alkalynization and acidification. The intracellular $\mathrm{pH}$ was calculated as described by the maker. Briefly, the formula used was $\left.\left[\mathrm{H}^{+}\right]=\mathrm{K}_{\mathrm{a}} \cdot\left(\left(\mathrm{R}-\mathrm{R}_{\mathrm{a}}\right) /\left(\mathrm{R}_{\mathrm{B}}-\mathrm{R}\right)\right) .\left(\mathrm{F}_{\mathrm{A}(\lambda 2)}\right) / \mathrm{F}_{\mathrm{B}(\lambda 2)}\right)$, where $\mathrm{R}$ is the $\mathrm{F}_{(\lambda 1)} / \mathrm{F}_{(\lambda 2)}$ ratio of fluorescence intensities (F) measured at two wavelengths $\lambda 1=490 \mathrm{~nm}$ and $\lambda 2=440 \mathrm{~nm}$ and the subscripts $\mathrm{A}$ and $\mathrm{B}$ represent the limiting values at the acidic and basic endpoints of the titration, respectively.

\section{C. elegans culture and strains}

C. elegans were cultured using standard techniques at $20^{\circ} \mathrm{C}$ on normal growth media (NGM) agar plates (Brenner, 1974). Synchronized young adults were used in the experiments. Strains were: Bristol N2 (wild-type); KWN85 (him-5(e1490)V, uIs22 (Pmec-18::GFP)V).

\section{C. elegans anoxia-starvation (AS)}

IR in C. elegans was simulated by promoting anoxia-starvation (AS) followed by reoxygenation and feeding, as previously described (Scott et al., 2002; Wojtovich et al., 2011; Wojtovich et al., 2012). C. elegans young adults were collected from NGM plates, washed 3 times and resuspended in M9 media $\left(22 \mathrm{mM} \mathrm{KH}_{2} \mathrm{PO}_{4}, 42 \mathrm{mM} \mathrm{Na}_{2} \mathrm{HPO}_{4}, 86 \mathrm{mM}\right.$ $\mathrm{NaCl}, 1 \mathrm{mM} \mathrm{MgSO}_{4}, \mathrm{pH}=7.0$ ) supplemented with $20 \mathrm{mM}$ HEPES. The animals were incubated in $100 \mu \mathrm{L}$ of M9 in an open eppendorf tube at $26^{\circ} \mathrm{C}$ for $20 \mathrm{~h}$ under either $100 \% \mathrm{~N}_{2}$ or $90 \% \mathrm{~N}_{2}$ and $10 \% \mathrm{CO}_{2}$. After AS, C. elegans were moved to a seeded plate with a minimal amount of M9 and left to recover for another $24 \mathrm{~h}$, then scored by an unblinded observer for viability and sensitivity to touch. 


\section{C. elegans neuron imaging}

Animals were transferred to a $2 \%$ M9 agarose pad containing $0.1 \%$ tetramisole and $0.1 \%$ tricaine (EMS, Hatfield, PA) and were imaged within 20 minutes of being placed under a coverslip. A Nikon Eclipse TE2000-U microscope (Nikon USA, Melville, NY), Polychrome $\mathrm{V}$ monochromator (TILL Photonics, Germany) and Cooke Sensicam CCD (PCO-TECH Inc., Romulus, MI) were coordinated using TILLvisION software to obtain fluorescent images (470-nm excitation/535-nm emission) under a 100× oil objective.

\section{Western blots}

Western blots used $12 \%$ denaturating gels. Gels were transferred (4 hours, $400 \mathrm{mV}$ ) onto PVDF membranes. Protein was quantified by the Bradford technique. For carbonylation detection, $5 \mu \mathrm{g}$ of protein were used per lane. Detection of 3-nitrotyrosine and methionine sulfoxide residues used $10 \mu \mathrm{g}$ of protein.

The samples from hearts and cells were prepared by homogenizing the tissue or the cells in the presence of a RIPA buffer (135 mM NaCl, $50 \mathrm{mM}$ Tris-HCl, $1 \%$ Nonidet P-40, $0.5 \%$ sodium deoxycholate, $0.1 \%$ SDS, and 1:10 Sigma proteinase inhibitor cocktail, $\mathrm{pH} 8$ ) and frozen at $-80^{\circ} \mathrm{C}$ until use. For $C$. elegans samples, the live worms were selected after reperfusion and resuspended in buffer previously described by Budas et al., 2010 (0.2 M Tris-HCl, $100 \mathrm{mM}$ DTT, 20\% glycerol, 10\% SDS and 1:10 Sigma proteinase inhibitor cocktail, $\mathrm{pH}$ 8), and submitted to 3 freeze/thaw cycles (liquid nitrogen/boiling water) and frozen at $-80^{\circ} \mathrm{C}$ until use.

For the carbonylation Western blots, samples were treated as described before (Nakamura and Goto, 1996; da Cunha et al., 2011) or the Oxyblot kit from Milipore was used and the reactions were done as described by the manufacturer. Briefly, we added SDS to the samples to reach a final concentration of $12 \%$ then submitted the proteins to a reaction with 2,4dinitrophenylhydrazine (DNPH) for $30 \mathrm{~min}$ followed by the addition of a neutralization buffer. For detection, we used 1:5000 anti-DNP antibody from Sigma, and 1:7000 antirabbit from Calbiochem. For other Western blots, we added the protein with sample buffer $(20 \mu \mathrm{g})$. Antibody concentrations were: anti-nitrotyrosine from Upstate, 1:5000; and antimouse from Calbiochem, 1:5000; anti-methionine sulfoxide from Upstate, 1:5000 and antirabbit from Calbiochem, anti-phospho-Akt(Ser473) from Cell Signaling, 1:5000.

The blots were scanned and analyzed using Image J. Images were converted to 8 bits color and intensities of the whole lane were included. Blots were compared to the $0 \% \mathrm{CO}_{2}$ control or to the $0 \% \mathrm{CO}_{2}$ ischemic group. In the 3-nitrotyrosine blot, we ran a standard amount of nitrated protein to quantify modified tyrosine.

\section{Statistics}

All experiments presented were replicated at least three times, and statistical analysis was conducted using GraphPad Prism 5. Panels A, B, D and E from Figure 2 were analyzed using 2-way ANOVA followed by Bonferroni correction, while all other data were analyzed using Student t-tests. Correlations were analyzed using linear fits. Differences were considered significant if $\mathrm{p}<0.05$. 


\section{Results}

Our aim in this work was to evaluate the impact of $\mathrm{CO}_{2} / \mathrm{HCO}_{3}{ }^{-}$on oxidative and functional tissue damage under the pathologically relevant condition of IR. Since $\mathrm{CO}_{2} / \mathrm{HCO}_{3}{ }^{-}$is a vital buffer, and we wished to focus on the effects of $\mathrm{CO}_{2} / \mathrm{HCO}_{3}{ }^{-}$itself, and not changes in $\mathrm{pH}$, all extracellular solutions used in this study were buffered using HEPES, and the $\mathrm{pH}$ was carefully adjusted after gassing. Additionally, we questioned if, despite the clamped $\mathrm{pH}$, changes in extracellular $\mathrm{CO}_{2} / \mathrm{HCO}_{3}{ }^{-}$concentrations could result in alterations in intracellular $\mathrm{pH}$. In order to address this question, we used cardiac HL-1 cells, a cell line which maintains cardiac phenotypes and has been extensively used to study cardiac IR (Fig. 1, Claycomb et al., 1998; White et al., 2004, Facundo et al., 2006). Cells were loaded with the intracellular $\mathrm{pH}$ probe $\mathrm{BCECF}$, and intracellular $\mathrm{pH}$ was measured in the absence or presence of $\mathrm{CO}_{2} / \mathrm{HCO}_{3}{ }^{-}$(indicated as the percentage of gassed $\mathrm{CO}_{2}, 0 \%$ or $10 \%$ ). We found that intracellular $\mathrm{pH}$ was indistinguishable under both incubation conditions (Fig. 1A). Thus, the conditions established allow for the evaluation of the biological role of $\mathrm{CO}_{2} / \mathrm{HCO}_{3}{ }^{-}$ independently of changes in physiological intracellular $\mathrm{pH}$.

We then submitted the cells to simulated IR (see Materials and Methods) in the presence of 0 and $10 \% \mathrm{CO}_{2}$ (Fig. 1B). We found that after IR, cells incubated in buffer containing $\mathrm{CO}_{2} / \mathrm{HCO}_{3}{ }^{-}$(full bars, $95 \mathrm{~min}$ IR) had significantly lower viability compared to cells incubated in the absence of $\mathrm{CO}_{2} / \mathrm{HCO}_{3}{ }^{-}$(open bars). Indeed, cell viability in the absence of $\mathrm{CO}_{2}$ was similar to that of cells submitted to $95 \mathrm{~min}$ incubation and centrifugations, but not IR. Cell viability before the ischemic intervention $(0 \mathrm{~min})$ and under non-ischemic conditions (95 min) was similar in both $\mathrm{CO}_{2} / \mathrm{HCO}_{3}{ }^{-}$-containing and $0 \% \mathrm{CO}_{2}$ groups, indicating that changes in $\mathrm{CO}_{2} / \mathrm{HCO}_{3}{ }^{-}$levels do not affect cell viability under physiological conditions, but exacerbate cell death after IR.

In order to verify if the loss of cell survival was associated with oxidative damage, we measured protein carbonyls in cell lysates. We found that incubation and centrifugation of samples during $95 \mathrm{~min}$ in the absence of IR increased carbonyl levels slightly relative to baseline in both 0 and $10 \% \mathrm{CO}_{2}$ (Fig. 1C, $95 \mathrm{~min}$ ). However, after 95 min IR, very significant increments in protein carbonyl levels were observed, and this increase was substantially larger in $10 \% \mathrm{CO}_{2}$ samples. Together, these results demonstrate that the presence of $\mathrm{CO}_{2} / \mathrm{HCO}_{3}{ }^{-}$substantially affects cell survival and oxidative damage after IR in cardiac cells.

Given the striking results of changes in $\mathrm{CO}_{2} / \mathrm{HCO}_{3}{ }^{-}$concentrations in cells submitted to IR, we sought next to evaluate the effects of these on ischemic hearts. Langendorff-perfused rat hearts were either maintained for 150 min without any intervention (non-ischemic) or submitted to IR as described in Materials and Methods (Fig. 2). We found that different gassed $\mathrm{CO}_{2}$ concentrations $(0,5$ or $10 \%)$ did not affect non-ischemic heart beat rates (BPM, Fig. 2A) or left ventricular developed pressure (Fig. 2B), a measure of cardiac function. Furthermore, different $\mathrm{CO}_{2}$ concentrations did not affect activating Akt phosphorylation, a known determinant of infarct injury (results not shown). On the other hand, ischemic hearts perfused with $10 \% \mathrm{CO}_{2}$ presented severely decreased BPM (Fig. 2D) and change in developed pressure (Fig. 2E) during reperfusion; the difference was significant both when 
comparing the curves point by point (as shown in the figures) and integrating the area under the curve at reperfusion ( $\mathrm{p}<0.05$ comparing 0 and $10 \% \mathrm{CO}_{2}$ using a t-test, for both BPM and developed pressure). Indeed, $10 \% \mathrm{CO}_{2}$ hearts displayed an infarcted area which was double of that observed in $0 \% \mathrm{CO}_{2}$ IR hearts (Fig. 2F). Overall, these results confirm, in a whole heart model, that $\mathrm{CO}_{2} / \mathrm{HCO}_{3}{ }^{-}$levels are determinant toward functional cardiac recovery after IR.

In order to evaluate if the changes in cardiac function observed were associated with oxidative damage, we measured protein carbonyl levels. While carbonyls were unaltered under different incubation conditions in non-ischemic hearts (results not shown), in IR hearts, protein carbonyl levels increased in proportion to the percent of gassed $\mathrm{CO}_{2}$ (Fig. $3 \mathrm{~A}$ ), and were more than $50 \%$ higher in $10 \% \mathrm{CO}_{2}$ relative to the absence of this gas. Similar increases in methionine sulfoxide (Fig. 3B) and nitro-tyrosine (Fig. 3C) residue levels were also observed in $10 \% \mathrm{CO}_{2}$ tissues. These protein modifications were undetectable in nonischemic heart samples perfused with any concentration of $\mathrm{CO}_{2}$. Again, our results suggest that, while different $\mathrm{CO}_{2} / \mathrm{HCO}_{3}{ }^{-}$do not overtly affect hearts under physiological conditions, they are determinant in functional and oxidative damage following IR.

The detection of increased nitro-tyrosine radicals in hearts perfused with $\mathrm{CO}_{2}$ indicates the participation of nitric oxide-derived species in cardiac damage enhanced by $\mathrm{CO}_{2}$. Indeed, peroxynitrite in the presence of $\mathrm{CO}_{2}$ is very efficient in promoting tyrosine nitration due to the production of nitrogen dioxide and the carbonate radical anion (reviewed in Medinas et al, 2007). In order to investigate a potential role for nitric oxide-derived oxidants in this process, we measured the effect of L-NAME, an inhibitor of nitric oxide synthases, on $\mathrm{CO}_{2}$ enhanced cardiac damage following IR (Fig. 4). We found that cardiac damage increases promoted by $\mathrm{CO}_{2}$ persisted in the presence of L-NAME. While this result suggests nitric oxide synthases are not involved in the effects of $\mathrm{CO}_{2}$, a role for nitric oxide cannot be excluded since it can be produced through nitrite reduction during ischemia (Zweier et al., 1995; Webb et al., 2004).

We next evaluated the effect of $\mathrm{CO}_{2} / \mathrm{HCO}_{3}{ }^{-}$on protein carbonyl formation in C. elegans during anoxia/starvation (AS), as a model for worm IR. Behavior and cell morphology were also assessed in the surviving worms. We found that $\mathrm{CO}_{2}$ had little apparent effect in the absence of AS (results not shown), while survival following AS was not altered by 0 or $10 \%$ $\mathrm{CO}_{2}$ either (AS, Fig. 5A). Protein carbonyls under AS conditions tended, non-significantly, to increase in $10 \% \mathrm{CO}_{2}$ (Fig. 5B). Interestingly however, surviving animals exhibited subtle but significant differences in behavior, manifested as an increased defective response to light body wall touch as a function of $\mathrm{CO}_{2}$ during hypoxia (Fig. $5 \mathrm{C}$ ). The behavioral response to body wall touch is mediated by six mechanosensory neurons whose processes run just under the hypodermis of the animal. In order to investigate if the decrease in function in these animals was accompanied by damage to these neurons, an integrated transgene was used to label the touch cells with GFP, and two of these neurons (PLML and PLMR) were examined in detail, as described (Materials and Methods). Neuronal abnormalities that were scored included the appearance of GFP inclusions in the processes, tortuous processes and breaks, all of which have been shown to accumulate as a result of hypoxia (Dasgupta et al., 2007). The incidence of such abnormalities was significantly increased by AS in $10 \% \mathrm{CO}_{2}$ 
compared to $0 \% \mathrm{CO}_{2}$ (Fig 6) demonstrating that, in a whole organism model, higher $\mathrm{CO}_{2} / \mathrm{HCO}_{3}{ }^{-}$promoted more significant tissue and functional damage following AS.

\section{Discussion}

Considering its role as the main biological buffer, it is surprising so little recent attention has been given to the biological activity of $\mathrm{CO}_{2} / \mathrm{HCO}_{3}{ }^{-}$(Medinas et al., 2007; Guais et al., 2011). In particular, metabolic and redox effects of this buffer are expected. In this work, we evaluated the results of different tensions of $\mathrm{CO}_{2}$, incurring in different $\mathrm{CO}_{2} / \mathrm{HCO}_{3}{ }^{-}$levels.

Using cardiac cells, perfused rat hearts and C. elegans, we found that increased $\mathrm{CO}_{2} / \mathrm{HCO}_{3}{ }^{-}$ heightened the injury associated with IR (Figs. 1-3, Khandoudi et al., 1995). Previous studies have determined that increased levels of $\mathrm{CO}_{2}$ result in increased heart beat rates (Stinson and Mattsson, 1970), but no change in pumping function (Wexels and Mjøs, 1987). However, these changes were completely reversed by normalizing $\mathrm{pH}$, indicating that they are related to $\mathrm{pH}$, and not to other possible biological activities of $\mathrm{CO}_{2} / \mathrm{HCO}_{3}{ }^{-}$. These data, in fact, correlate well with our finding that changes in $\mathrm{CO}_{2} / \mathrm{HCO}_{3}{ }^{-}$in the presence of clamped perfusion $\mathrm{pH}$ do not alter the basal function of perfused rat hearts (Fig. 2). On the other hand,Lavani et al. (2007) found that reperfusion in the presence of high $\mathrm{CO}_{2}$ tensions resulted in protection against cardiac damage. This result differs from ours, in which we found that higher cardiac damage in the presence of high $\mathrm{CO}_{2}$ tensions. Since Lavani et al (2007) did not correct for $\mathrm{pH}$ changes, and acidic $\mathrm{pH}$ is strongly protective in cardiac ischemia (Kitakaze et al., 1988; Schäfer et al., 2000), it seems reasonable to propose that their effects also are attributable to $\mathrm{pH}$ changes promoted by altered $\mathrm{CO}_{2}$ tensions. Our work separated the $\mathrm{pH}$ effect of $\mathrm{CO}_{2}$ from other biological effects by clamping $\mathrm{pH}$ with high concentrations of other buffers. Although we could not ascertain that this extracellular $\mathrm{pH}$ clamping maintained intracellular $\mathrm{pH}$ in perfused hearts and C. elegans, measured intracellular $\mathrm{pH}$ was identical in cells incubated in the presence and absence of $\mathrm{CO}_{2} / \mathrm{HCO}_{3}{ }^{-}$ (Fig. 1A), indicating that changes in $\mathrm{pH}$ are not necessary for the detrimental effects of $\mathrm{CO}_{2}$.

Under these conditions, it was possible to focus on the redox effects of $\mathrm{CO}_{2} / \mathrm{HCO}_{3}{ }^{-}$under basal conditions and IR. The presence of $\mathrm{CO}_{2}$ in solution allows for the generation of the highly reactive carbonate radical from the reaction of $\mathrm{CO}_{2}$ with peroxynitrite. $\mathrm{CO}_{2}$ also reacts with $\mathrm{H}_{2} \mathrm{O}_{2}$, producing peroxymonocarbonate, which is a better two-electron oxidant than $\mathrm{H}_{2} \mathrm{O}_{2}$ and decomposes to the carbonate radical in the presence of biologically ubiquitous metal ions (Ramirez et al, 2005; Medinas et al., 2010). The carbonate radical does not produce any known stable target-adducts and is therefore difficult to detect in vivo and even in vitro (Medinas et al., 2007). Peroxymonocarbonate and other oxidants may also be derived from bicarbonate. Thus, we investigated if changing $\mathrm{CO}_{2} / \mathrm{HCO}_{3}{ }^{-}$altered markers of tissue redox state.

Levels of protein carbonyls, the only modification detected in the absence of IR, were not altered by $\mathrm{CO}_{2} / \mathrm{HCO}_{3}{ }^{-}$under non-ischemic conditions in any of the models studied. This result is not unexpected, since bicarbonate-derived oxidants are produced secondarily to reactions promoted by other reactive oxygen and nitrogen species, which are much more abundant following IR. Indeed, we found that in both cardiac cells and perfused hearts (Figs. 
1 and 3), levels of oxidized proteins following IR increase markedly with the presence and increasing levels of $\mathrm{CO}_{2} / \mathrm{HCO}_{3}{ }^{-}$. In fact, a linear correlation was detected between carbonylated protein $\left(\mathrm{r}^{2}=0.995, \mathrm{p}=0.01\right)$ and methionine sulfoxide $\left(\mathrm{r}^{2}=0.9881, \mathrm{p}=0.06\right)$ and $\mathrm{CO}_{2}$ levels. Changes in protein modifications were not significantly increased in $C$. elegans, although they tended to be higher; it should be pointed out that AS in C. elegans requires $20 \mathrm{~h}$ after reoxygenation to produce notable functional effects, and the long reperfusion time may result in the removal of many modified proteins. Despite the lack of strong evidence for changes in redox state in the C. elegans system, $\mathrm{CO}_{2} / \mathrm{HCO}_{3}{ }^{-}$affected the functional recovery of the worms following AS (Figs. 5 and 6), once again demonstrating the importance of bicarbonate in ischemic damage.

Overall, our results show that over a wide range of experimental models (cells, organs and whole organisms), the presence of $\mathrm{CO}_{2} / \mathrm{HCO}_{3}{ }^{-}$promotes a strong decrease in function following IR, in a manner correlated with tissue oxidative damage. This demonstrates that $\mathrm{CO}_{2} / \mathrm{HCO}_{3}{ }^{-}$levels are determinant toward the outcome of pathologically relevant conditions of oxidative imbalance, and may explain the protective effect of modulating carbonic anhydrases (Ahmad S. 2000; Räisänen et al., 1999). While $\mathrm{CO}_{2} / \mathrm{HCO}_{3}{ }^{-}$are unavoidable in biological systems, our data provides a gain in understanding of the mechanisms involved in tissue damage following ischemic insults we hope will be important for future development of therapeutic interventions. Furthermore, our results provide evidence, albeit indirect, for the participation of bicarbonate radicals in pathologically relevant biological processes, and indicate that more attention should be focused on the redox biology of the $\mathrm{CO}_{2} / \mathrm{HCO}_{3}{ }^{-}$buffer.

\section{Acknowledgments}

This work was supported by the Fundação de Amparo à Pesquisa do Estado de São Paulo (FAPESP), Instituto Nacional de Ciência e Tecnologia de Processos Redox em Biomedicina (INCT Redoxoma), Núcleo de Apoio à Pesquisa Redoxoma (NAP Redoxoma), USPHS NS064945 (KN), USPHS GM087483 (PSB \& KN). BBQ is a doctoral student supported by a FAPESP grant and an American Society for Biochemistry and Molecular Biology PROLAB award. We would like to gratefully acknowledge Camille Caldeira da Silva, Edson Alves Gomes and Doris Araújo for their technical support, and Silvania Neves and the staff of the animal facilities for excellent animal care.

\section{Abbreviations}

$\begin{array}{ll}\text { DNPH } & \text { 2,4-dinitrophenylhydrazine } \\ \text { BCECF } & \text { 2'-7'-bis(carboxyethyl)-5(6)-carboxyfluorescein } \\ \text { BPM } & \text { beats per minute } \\ \text { DTT } & \text { dithiothreitol } \\ \text { IR } & \text { ischemia-reperfusion } \\ \text { AS } & \text { anoxia-starvation } \\ \text { NGM } & \text { normal growth media } \\ \text { PLML } & \text { posterior lateral microtubule cell left } \\ \text { PLMR } & \text { posterior lateral microtubule cell right }\end{array}$


$\begin{array}{ll}\text { ROS } & \text { reactive oxygen species } \\ \text { SDS } & \text { sodium dodecyl sulfate }\end{array}$

\section{Bibliography}

Ahmad S. Acetazolamide and enalapril combination offers complete protection from nitric oxidedeficient stroke in stroke-prone spontaneously hypertensive rats. Pharmacol. Res. 2000; 41:649656. [PubMed: 10816334]

Arai H, Berlett BS, Chock PB, Stadtman ER. Effect of bicarbonate on iron-mediated oxidation of lowdensity lipoprotein. Proc. Natl. Acad. Sci. USA. 2005; 102:10472-10477. [PubMed: 16027354]

Bonini MG, Miyamoto S, Di Mascio P, Augusto O. Production of the carbonate radical anion during xanthine oxidase turnover in the presence of bicarbonate. J. Biol. Chem. 2004; 279:51836-51843. [PubMed: 15448145]

Brenner S. The genetics of Caenorhabditis elegans. Genetics. 1974; 77:71-94. [PubMed: 4366476]

Budas GR, Disatnik MH, Chen CH, Mochly-Rosen D. Activation of aldehyde dehydrogenase 2 (ALDH2) confers cardioprotection in protein kinase C epsilon (PKCvarepsilon) knockout mice. J. Mol. Cell Cardiol. 2010; 48:757-764. [PubMed: 19913552]

Cardoso AR, Chausse B, da Cunha FM, Luévano-Martínez LA, Marazzi TBM, Pessoa PS, Queliconi BB, Kowaltowski AJ. Mitochondrial compartmentalization of redox processes. Free Radic. Biol. Med. (in press).

Claycomb WC, Lanson NA Jr, Stallworth BS, Egeland DB, Delcarpio JB, Bahinski A, Izzo NJ Jr. HL-1 cells: a cardiac muscle cell line that contracts and retains phenotypic characteristics of the adult cardiomyocyte. Proc. Natl. Acad. Sci. USA. 1998; 95:2979-2984. [PubMed: 9501201]

da Cunha FM, Demasi M, Kowaltowski AJ. Aging and calorie restriction modulate yeast redox state, oxidized protein removal, and the ubiquitin-proteasome system. Free Radic. Biol. Med. 2011; 51:664-670. [PubMed: 21684330]

Dasgupta N, Patel AM, Scott BA, Crowder CM. Hypoxic preconditioning requires the apoptosis protein CED-4 in C. elegans. Curr. Biol. 2007; 17:1954-1959. [PubMed: 17980592]

Ezraty B, Chabalier M, Ducret A, Maisoneuve E, Dukan S. $\mathrm{CO}_{2}$ exacerbates oxygen toxicity. EMBO Rep. 2011; 12:321-326. [PubMed: 21350502]

Facundo HT, de Paula JG, Kowaltowski AJ. Mitochondrial ATP-sensitive $\mathrm{K}^{+}$channels prevent oxidative stress, permeability transition and cell death. J. Bioenerg Biomembr. 2005; 37:75-82. [PubMed: 15906152]

Facundo HT, Carreira RS, de Paula JG, Santos CC, Ferranti R, Laurindo FR, Kowaltowski AJ. Ischemic preconditioning requires increases in reactive oxygen release independent of mitochondrial $\mathrm{K}^{+}$channel activity. Free Radic. Biol. Med. 2006; 40:469-479. [PubMed: 16443162]

Fishbein MC, Meerbaum S, Rit J, Lando U, Kanmatsuse K, Mercier JC, Corday E, Ganz W. Early phase acute myocardial infarct size quantification: validation of the triphenyl tetrazolium chloride tissue enzyme staining technique. Am. Heart J. 1981; 101:593-600. [PubMed: 6164281]

Guais A, Brand G, Jacquot L, Karrer M, Dukan S, Grévillot G, Molina TJ, Bonte J, Regnier M, Schwartz L. Toxicity of carbon dioxide: a review. Chem. Res. Toxicol. 2011; 24:2061-2070. [PubMed: 21732636]

Hodgson EK, Fridovich I. The mechanism of the activity-dependent luminescence of xanthine oxidase. Arch. Biochem. Biophys. 1976; 172:202-205. [PubMed: 1252075]

Johnson D, Nehrke K. Mitochondrial fragmentation leads to intracellular acidification in Caenorhabditis elegans and mammalian cells. Mol. Biol. Cell. 2010; 21:2191-2201. [PubMed: 20444981]

Karsten U. Fluorometric estimation of dead cells in cell suspensions. Experientia. 1980; 36:263-264. [PubMed: 7371780] 
Khandoudi N, Bernard M, Cozzone P, Feuvray D. Mechanisms of intracellular pH regulation during postischemic reperfusion of diabetic rat hearts. Diabetes. 1995; 44:196-202. [PubMed: 7859941]

Kitakaze M, Weisfeldt ML, Marban E. Acidosis during early reperfusion prevents myocardial stunning in perfused ferret hearts. J. Clin. Invest. 1988; 82:920-927. [PubMed: 3417873]

Lavani R, Chang WT, Anderson T, Shao ZH, Wojcik KR, Li CQ, Pietrowski R, Beiser DG, Idris AH, Hamann KJ, Becker LB, Vanden Hoek TL. Altering $\mathrm{CO}_{2}$ during reperfusion of ischemic cardiomyocytes modifies mitochondrial oxidant injury. Crit. Care Med. 2007; 35:1709-1716. [PubMed: 17522572]

Liochev SI, Fridovich I. $\mathrm{CO}_{2}$ not $\mathrm{HCO}_{3}{ }^{-}$facilitates oxidations by $\mathrm{Cu}, \mathrm{Zn}$ superoxide dismutase plus $\mathrm{H}_{2} \mathrm{O}_{2}$. Proc. Natl. Acad. Sci. USA. 2004; 101:743-744. [PubMed: 14711995]

Martin A, Zulueta J, Hassoun P, Blumberg JB, Meydani M. Effect of vitamin E on hydrogen peroxide production by human vascular endothelial cells after hypoxia/reoxygenation. Free Radic. Biol. Med. 1996; 20:99-105. [PubMed: 8903685]

Medinas DB, Cerchiaro G, Trindade DF, Augusto O. The carbonate radical and related oxidants derived from bicarbonate buffer. IUBMB Life. 2007; 59:255-262. [PubMed: 17505962]

Medinas DB, Toledo JC Jr, Cerchiaro G, do-Amaral AT, de-Rezende L, Malvezzi A, Augusto O. Peroxymonocarbonate and carbonate radical displace the hydroxyl-like oxidant in the Sod1 peroxidase activity under physiological conditions. Chem. Res. Toxicol. 2009; 22:639-648. [PubMed: 19243126]

Medinas DB, Augusto O. Mechanism of the peroxidase activity of superoxide dismutase. Free Radic. Biol. Med. 2010; 49:682. [PubMed: 20553855]

Nakamura A, Goto S. Analysis of protein carbonyls with 2,4-dinitrophenyl hydrazine and its antibodies by immunoblot in two-dimensional gel electrophoresis. J. Biochem. 1996; 119:768774. [PubMed: 8743580]

Radi R. Nitric oxide, oxidants, and protein tyrosine nitration. Proc. Natl. Acad. Sci. USA. 2004; 101:4003-4008. [PubMed: 15020765]

Räisänen SR, Lehenkari P, Tasanen M, Rahkila P, Härkönen PL, Väänänen HK. Carbonic anhydrase III protects cells from hydrogen peroxide-induced apoptosis. FASEB J. 1999; 13:513-522. [PubMed: 10064618]

Ramirez DC, Mejiba SE, Mason RP. Copper-catalyzed protein oxidation and its modulation by carbon dioxide: enhancement of protein radicals in cells. J. Biol. Chem. 2005; 280:27402-27411. [PubMed: 15905164]

Rink TJ, Tsien RY, Pozzan T. Cytoplasmic pH and free Mg2+ in lymphocytes. J. Cell Biol. 1982; 95:189-196. [PubMed: 6815204]

Schäfer C, Ladilov YV, Siegmund B, Piper HM. Importance of bicarbonate transport for protection of cardiomyocytes against reoxygenation injury. Am. J. Physiol. Heart Circ. Physiol. 2000; 278:H1457-H1463. [PubMed: 10775122]

Scott BA, Avidan MS, Crowder CM. Regulation of hypoxic death in C. elegans by the insulin/IGF receptor homolog DAF-2. Science. 2002; 296:2388-2391. [PubMed: 12065745]

Stinson JM, Mattsson JL. Tolerance of rhesus monkeys to graded increase in environmental $\mathrm{CO}_{2}$ : Serial changes in heart rate and cardiac rhythm. Aerosp. Med. 1970; 41:415-418. [PubMed: 4393292]

Surmeli NB, Litterman NK, Miller AF, Groves JT. Peroxynitrite mediates active site tyrosine nitration in manganese superoxide dismutase. Evidence of a role for the carbonate Radical Anion. J. Am. Chem. Soc. 2010; 132:17174-17185. [PubMed: 21080654]

Vanden Hoek TL, Shao Z, Li C, Zak R, Schumacker PT, Becker LB. Reperfusion injury on cardiac myocytes after simulated ischemia. Am. J. Physiol. 1996; 270:H1334-H1341. [PubMed: 8967373]

Webb A, Bond R, McLean P, Uppal R, Benjamin N, Ahluwalia A. Reduction of nitrite to nitric oxide during ischemia protects against myocardial ischemia-reperfusion damage. Proc. Natl. Acad. Sci. USA. 2004; 101:13683-13688. [PubMed: 15347817]

Wexels JC, Mjøs OD. Effects of carbon dioxide and $\mathrm{pH}$ on myocardial function in dogs with acute left ventricular failure. Crit. Care Med. 1987; 15:1116-1120. [PubMed: 3119292] 
White SM, Constantin PE, Claycomb WC. Cardiac physiology at the cellular level: use of cultured HL-1 cardiomyocytes for studies of cardiac muscle cell structure and function. Am. J. Physiol. Heart Circ. Physiol. 2004; 286:H823-H829. [PubMed: 14766671]

Winterbourn CC. Reconciling the chemistry and biology of reactive oxygen species. Nat. Chem. Biol. 2008; 4:278-286. [PubMed: 18421291]

Wojtovich AP, Sherman TA, Nadtochiy SM, Urciuoli WR, Brookes PS, Nehrke K. SLO-2 is cytoprotective and contributes to mitochondrial potassium transport. PLoS One. 2011; 6:e28287. [PubMed: 22145034]

Wojtovich AP, DiStefano P, Sherman T, Brookes PS, Nehrke K. Mitochondrial ATP-sensitive potassium channel activity and hypoxic preconditioning are independent of an inwardly rectifying potassium channel subunit in Caenorhabditis elegans. FEBS Lett. 2012; 586:428-434. [PubMed: 22281198]

Zhang H, Andrekopoulos C, Joseph J, Chandran K, Karoui H, Crow JP, Kalyanaraman B. Bicarbonate-dependent peroxidase activity of human $\mathrm{Cu}, \mathrm{Zn}$-superoxide dismutase induces covalent aggregation of protein: intermediacy of tryptophan-derived oxidation products. J. Biol. Chem. 2003; 278:24078-24089. [PubMed: 12686560]

Zhou H, Singh H, Parsons ZD, Lewis SM, Bhattacharya S, Seiner DR, LaButti JN, Reilly TJ, Tanner JJ, Gates KS. The biological buffer bicarbonate/ $/ \mathrm{CO}_{2}$ potentiates $\mathrm{H}_{2} \mathrm{O}_{2}$-mediated inactivation of protein tyrosine phosphatases. J. Am. Chem. Soc. 2011; 133:15803-15805. [PubMed: 21913686]

Zweier JL, Wang P, Samouilov A, Kuppusamy P. Enzyme-independent formation of nitric oxide in biological tissues. Nat. Med. 1995; 1:804-809. [PubMed: 7585184] 

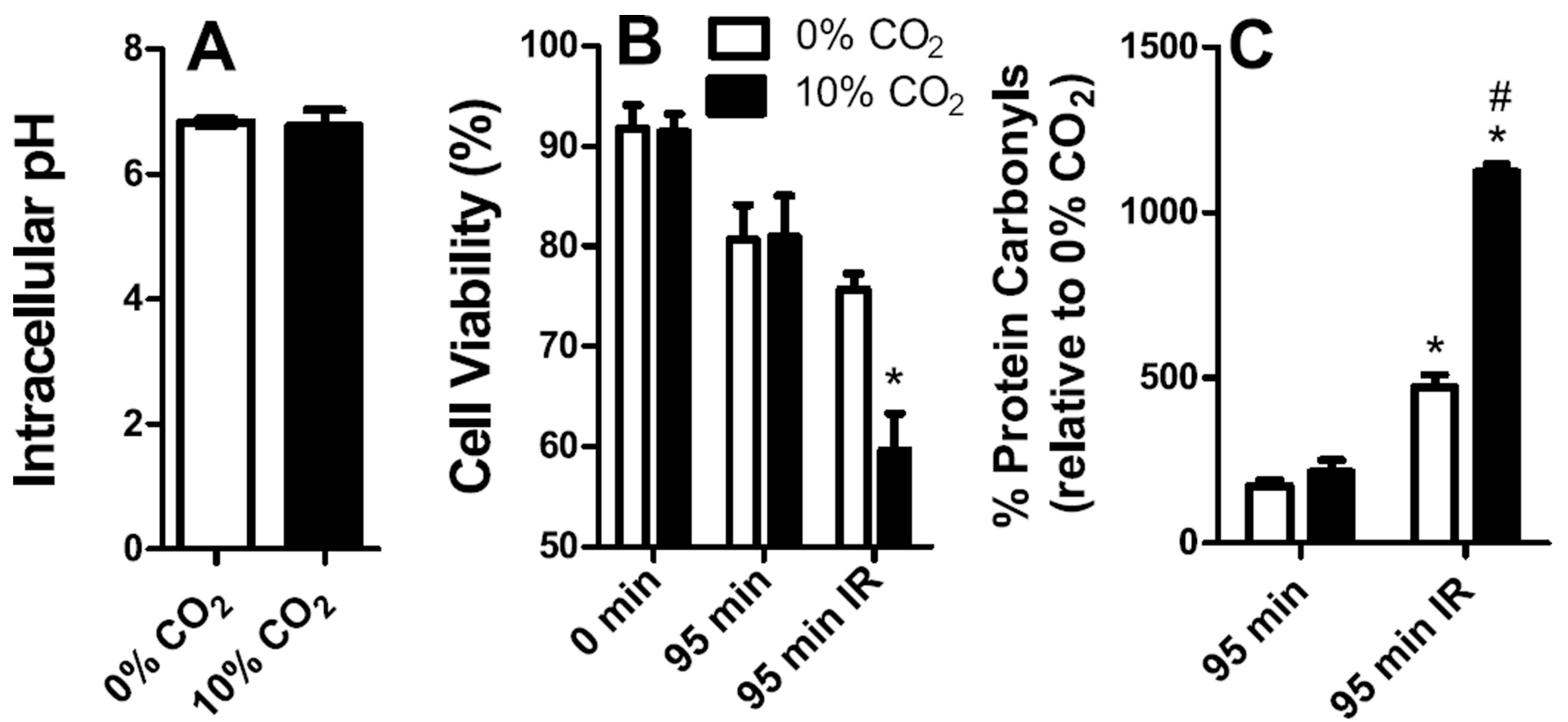

Fig. 1. Cardiac HL-1 cells present increased oxidative damage and loss of viability when submitted to IR in the presence of $\mathrm{CO}_{2}$ Panel A: Intracellular $\mathrm{pH}$ was measured as described in Materials and Methods, in the presence or absence of $\mathrm{CO}_{2}$, after 95 min stabilization. Panel B: Cell viability was measured in the absence (open bars) or presence (full bars) of $10 \% \mathrm{H}_{2} \mathrm{CO}_{3} / \mathrm{HCO}_{3}{ }^{-}$.

Cell viability was measured as described in Materials and Methods, at 0 and $95 \mathrm{~min}$, in the absence or presence of IR, as indicated. Panel C: Protein carbonyl levels were detected as described in Materials and Methods and are shown as percent of $0 \% \mathrm{CO}_{2}$ levels at $0 \mathrm{~min}$. *, $\mathrm{p}<0.05$ relative to non-ischemic, $95 \mathrm{~min} ;{ }^{*}, \mathrm{p}<0.05$ relative to $95 \mathrm{~min} \mathrm{IR}$ in $0 \% \mathrm{CO}_{2}$. 

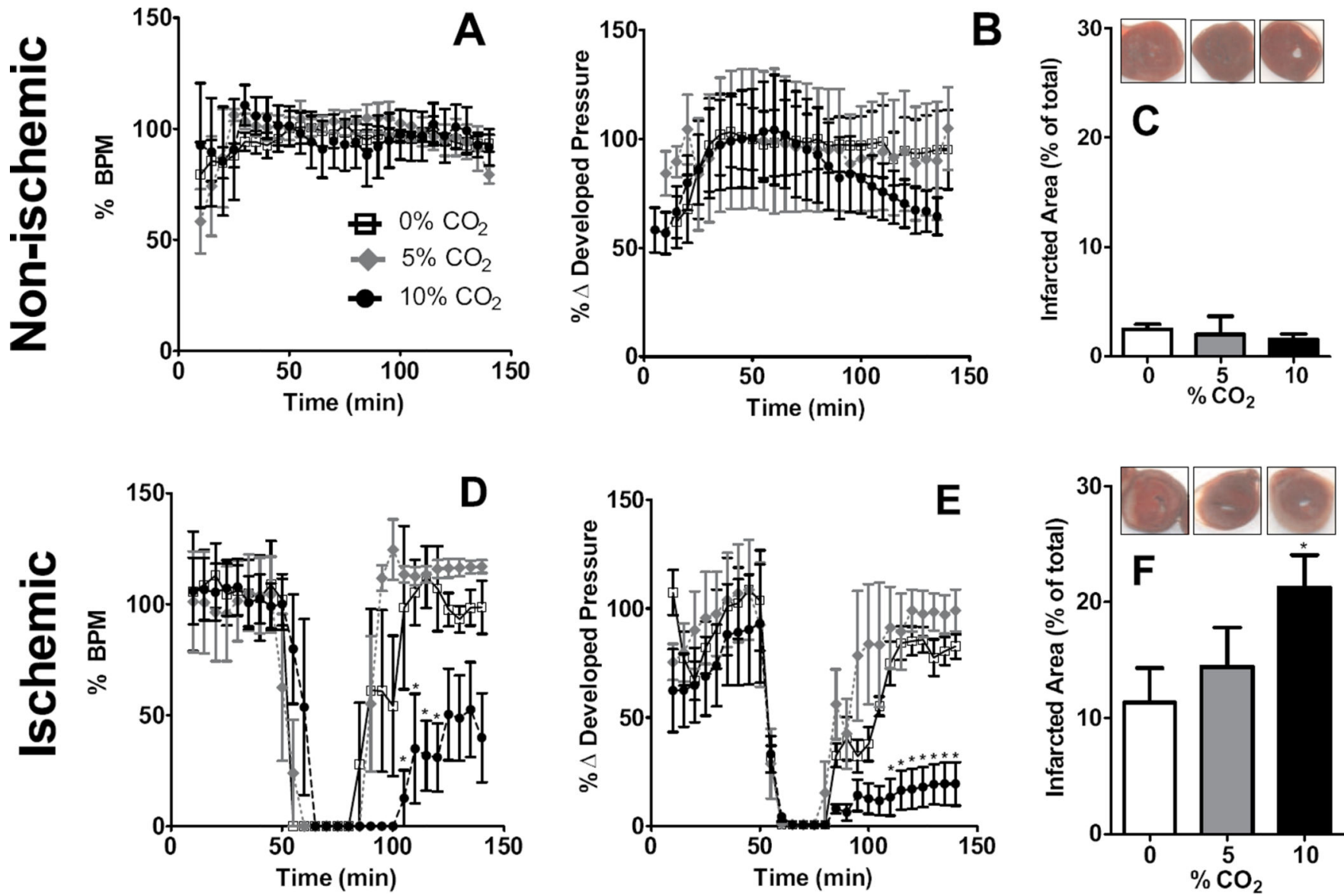

Fig. 2. Perfused rat hearts present increased functional loss when submitted to IR in the presence of $10 \% \mathrm{CO}_{2}$ Beats per minute (BPM, Panels A and D), left ventricular developed pressure (Panels B and E) and infarct areas (Panels C and F) were measured as described in Materials and Methods for non-ischemic (Panels A-C) or IR (Panels D-F) hearts perfused with $0 \%(\square), 5 \%(\diamond)$ or $10 \% \mathrm{CO}_{2}(\bullet)$. $*$ p $<0.05$ relative to IR with $0 \% \mathrm{CO}_{2}$ 

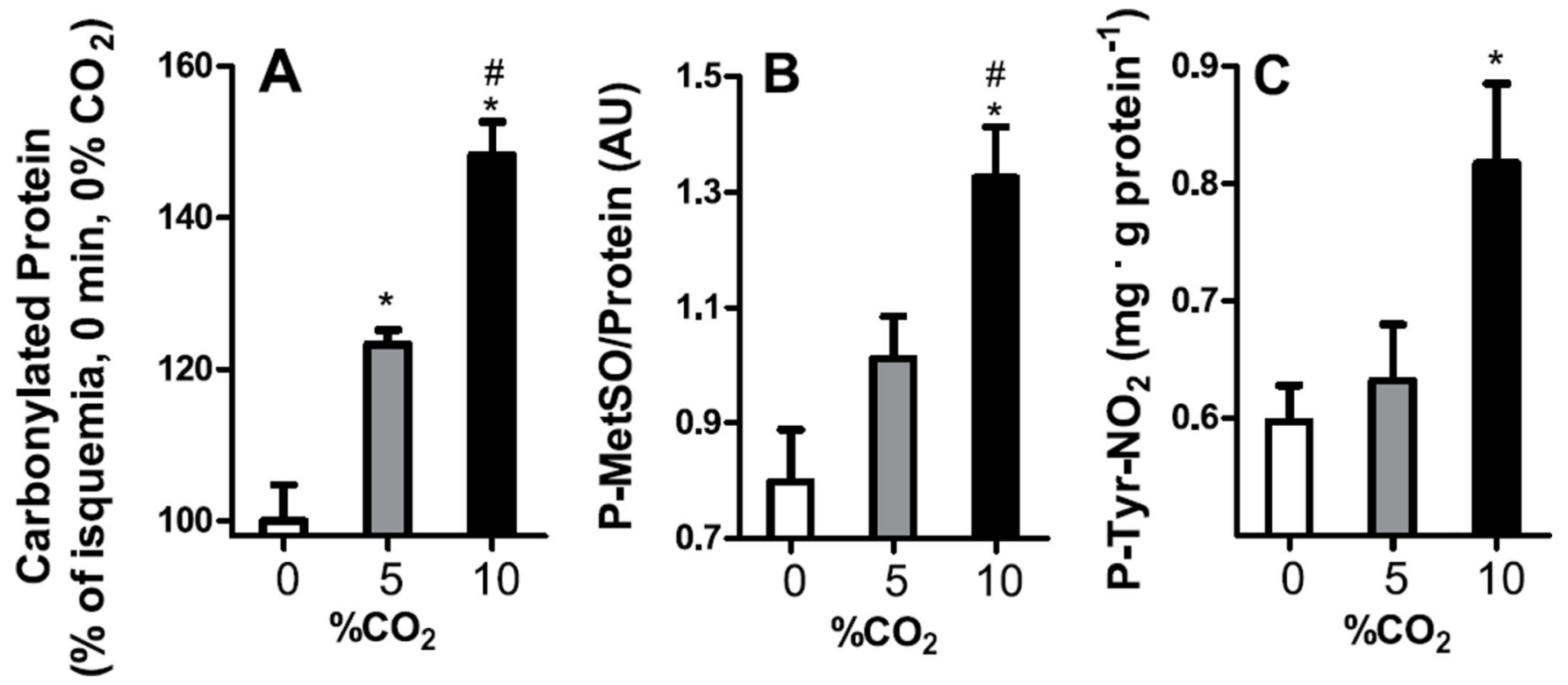

Fig. 3. Increases in $\mathrm{CO}_{2}$ are accompanied by enhanced oxidative damage in IR hearts

The amount of carbonylated proteins (A), methionine sulfoxide (B) and nitro-tyrosine (C) was quantified as described in Materials and Methods following IR conducted under the conditions of Fig. 2. *, p $<0.05$ relative to $0 \% \mathrm{CO}_{2}$; ${ }^{\#}$, p $<0.05$ relative to $5 \% \mathrm{CO}_{2}$. 

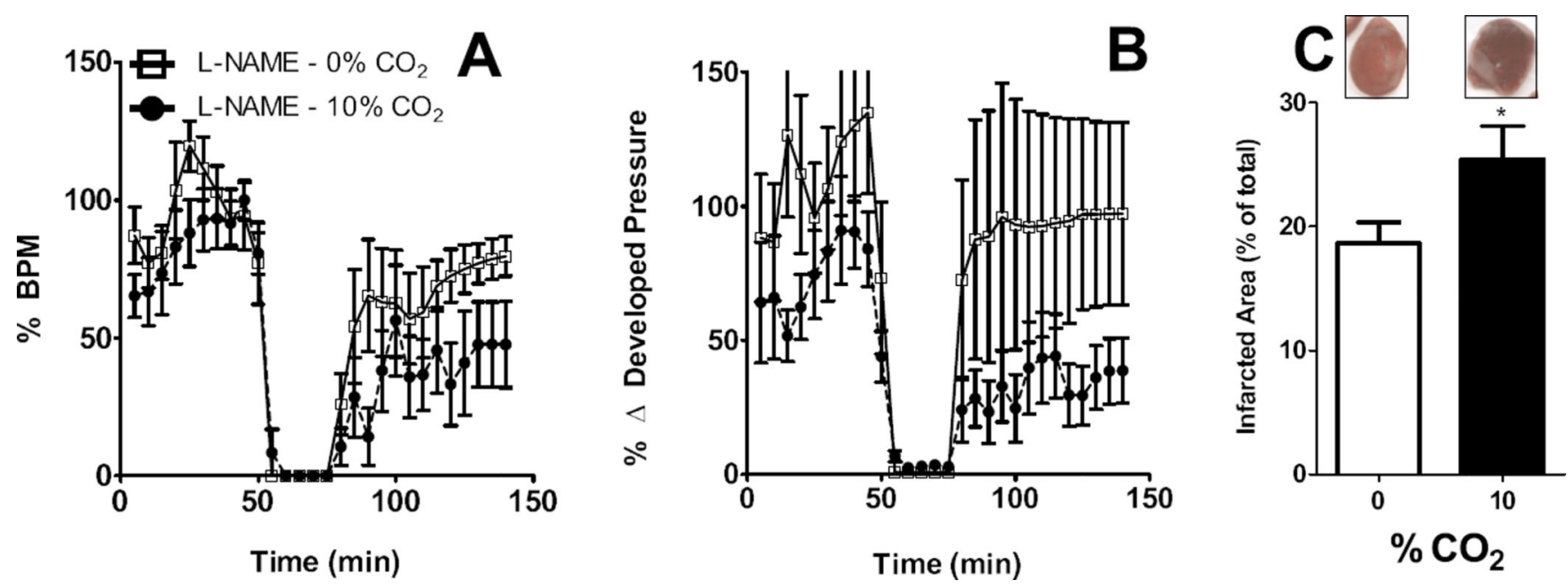

Fig. 4. L-NAME does not inhibit functional loss promoted by $\mathrm{CO}_{2}$ in IR hearts

Beats per minute (BPM, Panels A), left ventricular developed pressure (Panels B) and infarct areas (Panels C) were measured as in Fig. 2, with the addition of $200 \mu \mathrm{M}$ L-NAME to the perfusion media. *, p $<0.05$ relative to $0 \% \mathrm{CO}_{2}$. 

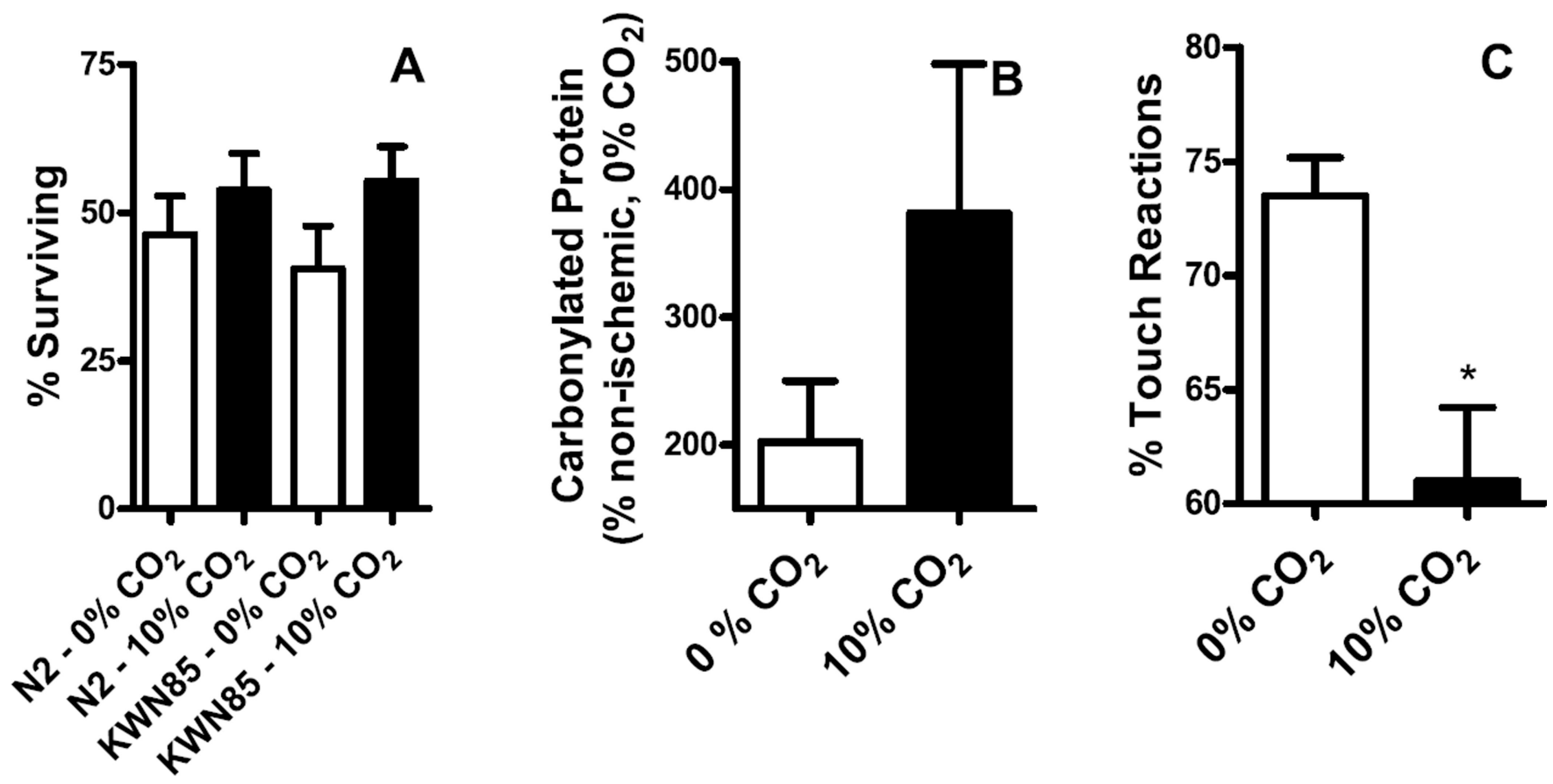

Fig. 5. 10\% $\mathrm{CO}_{2}$ decreases touch responses in C. elegans following IR, without affecting survival Panel A: The percentage of worms that exhibit 24-hr post-AS survival in the presence or absence of $\mathrm{CO}_{2}$ was measured as described in Material and Methods. The N2 strain is the canonical wild type genetic background, and KWN85 contains an integrated transgene that labels mechanosensory neurons with GFP. Panel B: Proteins were extracted from living C. elegans after AS in the presence or absence of $\mathrm{CO}_{2}$, and protein carbonyls were detected using an Oxyblot. Panel C: The response to touch stimuli of living C. elegans after AS in the presence or absence of $\mathrm{CO}_{2}$ was measured as described in Material and Methods. *, $\mathrm{p}<0.01$ relative to $0 \% \mathrm{CO}_{2}$. 

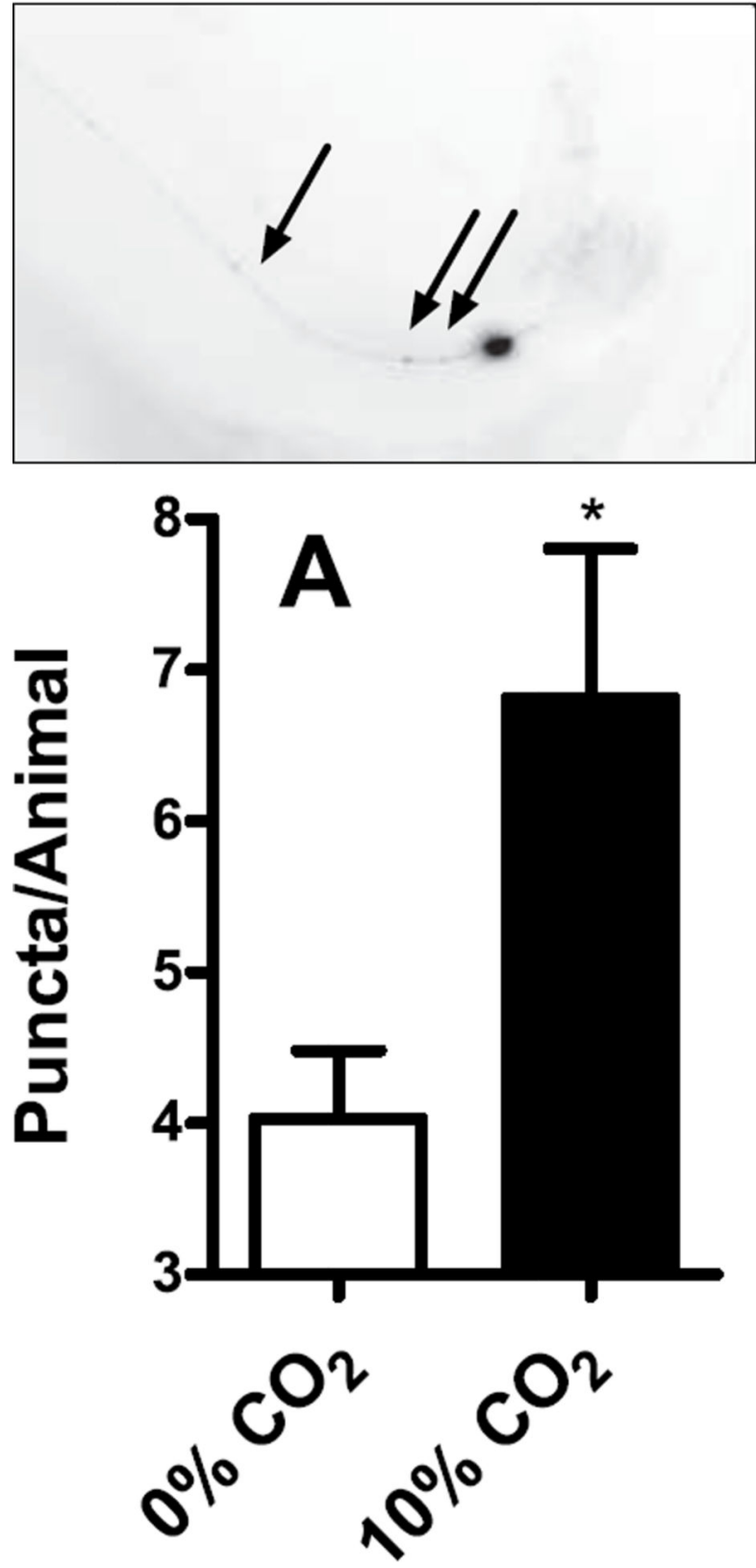
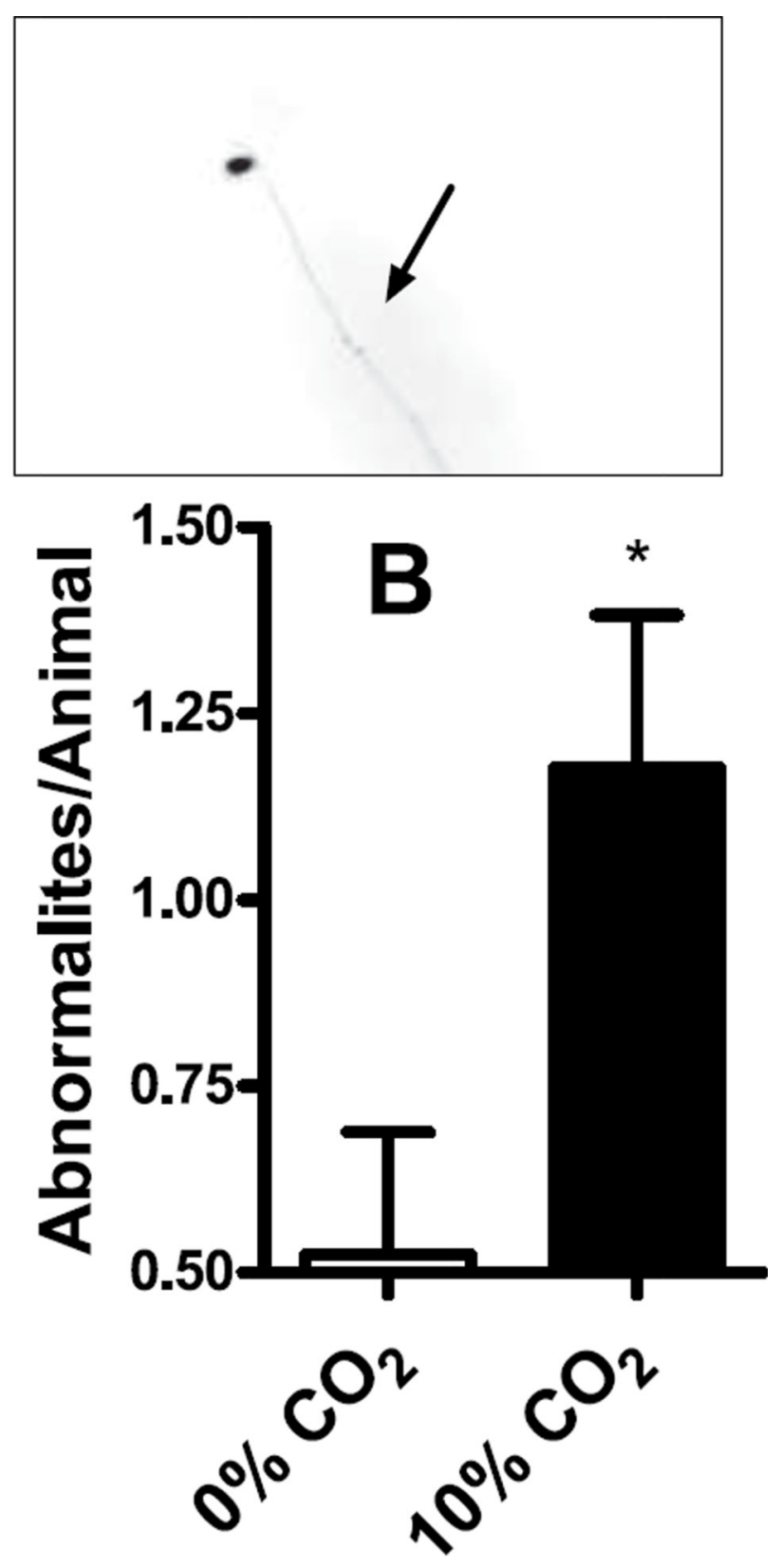

Fig. 6. $10 \% \mathrm{CO}_{2}$ increases touch neuron modifications

Touch neuron (PLML and PLMR) abnormalities such as tortuous processes and breaks (Panel A) or the accumulation of GFP aggregates in the processes (Panel B) were monitored in surviving anesthetized C. elegans after IR in the presence or absence of $\mathrm{CO}_{2}$, as described in Material Methods. ${ }^{*}, \mathrm{p}<0.05$ relative to $0 \% \mathrm{CO}_{2}$. 